\title{
REFERENCES
}

Dawson, J. B., 1964. Carbonate Tuff Cones in Northern Tanganyika, Geol. Mag., 101, 129-137.

Downie, C., and P. WILKInson, 1962. The explosion craters of Basotu, Tanganyika Territory. Bull. Volcanologique, 24, 389-420.

P. BOWDEN.

R. PICKERING.

Geological Survey of Tanganyika,

P.O. Box, 903 ,

DoDoma,

TANGANYIKA.

19th June, 1964.

Table 1.-Trace Elements in Tuffs, Calcareous Tuffs and Limestones.

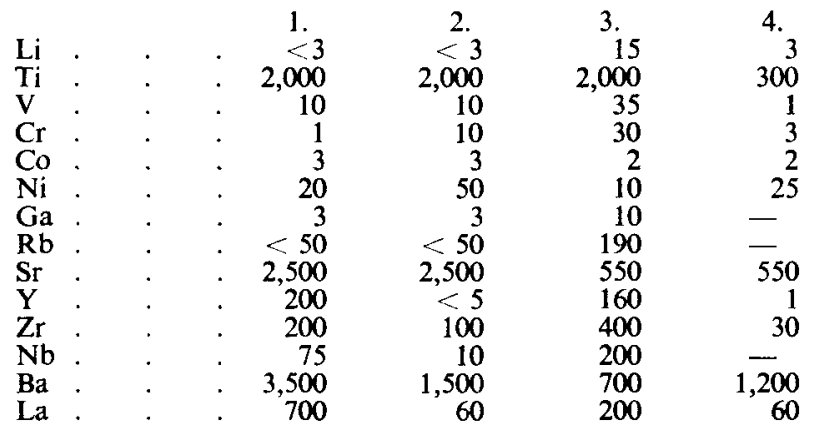

All values in parts per million.

Precision \pm 40 per cent.

1.) Calcareous tuffs, Longido.

3. Averaged data for twenty-four tuffs, calcareous tuffs and limestones, Serengeti region.

4. Averaged data for three carbonate tuffs, Dawson (1964), Table 1, analyses 4,6 , and 7 .

\section{THE PROBLEM OF THE SOURCE OF JADE USED FOR POLISHED STONE AXES IN BRITTANY}

SIR,-Since my paper on Jade axes from sites in the British Isles was printed, Professor Giot has brought to my notice further information bearing on the search for a source of jadeite in Brittany. This information is contained in a paper by J. Cogné and P. R. Giot (1957) on the petrography of the polished stone axes of Brittany and in two papers by J. Cogné on the crystalline schists and granites of southern Brittany.

In their 1957 paper the authors state that in some of the jade axes they have examined glaucophane and garnet occur associated with the pyroxene, and that this association of minerals is also to be found in some of the glaucophane-rocks of Ile de Groix. In the same paper they also record the finding "dans les champs" of a jadeite-rock with garnet associated with eclogite with glaucophane, presenting characters very near those of the Breton axes. This find was made near Bouvron to the north of Nantes.

The association of jadeite with glaucophane and garnet in the Ile de Groix is described by J. Cogné in his petrographic memoir (1960). He describes a 
glaucophanite in which a pyroxene occurs as a microscopic constituent sometimes forming up to 40 per cent of the rock. The optical properties of this pyroxene $\left(2 \mathrm{~V} 82^{\circ}-84^{\circ}\right.$, extinction angle $40^{\circ}-44^{\circ}$, birefringence 0.01$)$ place it in the sodic jadeite-acmite series near the chloromelanites. On this evidence in a later paper (1961, pp. 222-226) Cogné suggests that one might expect jadeitites with garnet and glaucophane to occur as a sort of end member of the basic rock series he finds developed on the south-east of the Ile de Groix between Pointe Saint-Nicolas and Pointe des Chats. Such rocks, however, have not been found hitherto.

J. Cogné also describes from the Bouvron area some eclogites containing a jadeitic diopside pyroxene, but the optical properties of this pyroxene are not stated.

Giot and Cogne consider that this new evidence indicates that the Ile de Groix and the Bouvron area are the regions of Brittany most likely to yield jadeite rocks but both authors separately re-state their previously expressed opinion that the original source of the jadeite of the axes has not yet been traced (1961) and that " in fact it is by no means proved that the origin of the raw material of the axes is Armoricain" (1957). It is evident, however, that they do not rule out the possibility of a partly local origin for some of them. In fact in a paper read at Rome in 1962, and at present unpublished, Professor Giot stated his opinion as follows [in translation] :

"As far as the ordinary polished axes in jadeitite, garnetiferous chloromelanitite and eclogite are concerned one can provisionally conclude that the majority of these in Brittany are made in material of local origin and that the material might have come from the occurrence at Bouvron (or perhaps from Ile de Groix) although the exposures near Bouvron appear actually to be worked out at the surface."

On another point in my paper I must make a correction. This refers to my comment on the claim made by $\mathbf{M}$. de Limur (1895) that chloromelanite and jadeite occurred in a band of rock in Ile d'Arz. I stated (p. 152) that Mlle. Brière had described the rock in question as an amphibolite containing no pyroxene of any kind. This was not so. Mlle Brière was describing only the amphibolites of the island. There are in fact bands of pyroxene rock present as recorded by J. Cogné $(1960$, p. 153) and previously by Barrois. However the pyroxene is not jadeite. The other rocks from Brittany that have been claimed in the past as the raw material of the axes in jade, namely the pyroxenegneiss of Roguédas and the similar rock from Port Navalo, are re-described by Cogné in his memoir referred to above (1960, pp. 151-153). He completely confirms what $I$ have written about these rocks.

\section{REFERENCES}

CoGNÉ, J., 1960. Schistes cristallins et Granites en Bretagne meridionale-La domaine de l'anticlinal de Corouaille. Mem Carte dét. France.

1961. Rémarques sur quelques-uns des principales associations minérales dans les micaschistes de Bretagne meridionale (FinistèreMorbihan). Bull. Soc. Franç. Min., 74, 222-226.

and P. R. Giot, 1957. Étude pétrographique des haches polies de Bretagne. Bull. Soc. Préh. Française, 54, p. 204.

GIot, P. R., 1962. Le problème européen des haches d'apparat en jadéitite et roches voisines. [In the Press.]

Smith, W. Campbell, 1964. Jade Axes from sites in the British Isles. Proc. Prehist. Soc., 29, 133-172.

British Museum (Natural History),

W. Campbell Smith.

Cromwell Road,

LONDON, S.W. 7.

9th July, 1964. 